\title{
Trends in educational inequalities in cause specific mortality in Norway from 1960 to 2010: a turning point for educational inequalities in cause specific mortality of Norwegian men after the millennium?
}

Bjørn Heine Strand ${ }^{1,2^{*}}$, Ólöf Anna Steingrímsdóttir ${ }^{1}$, Else-Karin Grøholt ${ }^{1}$, Inger Ariansen ${ }^{1}$, Sidsel Graff-Iversen ${ }^{1}$ and Øyvind Næss ${ }^{1,3}$

\begin{abstract}
Background: Educational inequalities in total mortality in Norway have widened during 1960-2000. We wanted to investigate if inequalities have continued to increase in the post millennium decade, and which causes of deaths were the main drivers.

Methods: All deaths (total and cause specific) in the adult Norwegian population aged 45-74 years over five decades, until 2010 were included; in all 708,449 deaths and over 62 million person years. Two indices of inequalities were used to measure inequality and changes in inequalities over time, on the relative scale (Relative Index of Inequality, RII) and on the absolute scale (Slope Index of Inequality, SII).
\end{abstract}

Results: Relative inequalities in total mortality increased over the five decades in both genders. Among men absolute inequalities stabilized during 2000-2010, after steady, significant increases each decade back to the 1960s, while in women, absolute inequalities continued to increase significantly during the last decade. The stabilization in absolute inequalities among men in the last decade was mostly due to a fall in inequalities in cardiovascular disease (CVD) mortality and lung cancer and respiratory disease mortality. Still, in this last decade, the absolute inequalities in cause-specific mortality among men were mostly due to cardiovascular diseases (CVD) (34\% of total mortality inequality), lung cancer and respiratory diseases (21\%). Among women the absolute inequalities in mortality were mostly due to lung cancer and chronic lower respiratory tract diseases (30\%) and CVD (27\%).

Conclusions: In men, absolute inequalities in mortality have stopped increasing, seemingly due to reduction in inequalities in CVD mortality. Absolute inequality in mortality continues to widen among women, mostly due to death from lung cancer and chronic lung disease. Relative educational inequalities in mortality are still on the rise for Norwegian men and women.

Keywords: Mortality, Education, Health inequalities, Norway, Nordic paradox

\footnotetext{
* Correspondence: heine@fhi.no

'Division of epidemiology, Norwegian Institute of Public Health, P.O. Box 4404

Nydalen, NO-0403 Oslo, Norway

${ }^{2}$ University of Oslo, Institute of Health and Society, Faculty of Medicine, Oslo,

Norway

Full list of author information is available at the end of the article
} 


\section{Background}

Why socioeconomic health inequalities persist and even widen in the modern welfare states of Western Europe has been denoted a paradox [1]. Even in the Nordic countries, where the welfare state regime is generous with a focus on equality, there have been widening inequalities in the last decades, both on an absolute and a relative scale [2-4]. The Nordic countries differ from other welfare state regimes [5], and stand out from the other Western European countries with lower level of income inequality, lower prevalence of poverty, generous social security benefits and a health care system mostly publicly funded [6].

Previously, we reported widening educational inequalities (both relative and absolute) in mortality among middle aged Norwegians in the period 1960-2000 [2]. Cardiovascular mortality was the main driver behind the inequalities the whole period. The increase in inequality during the period was driven by cardiovascular mortality in men, and by deaths due to chronic lower respiratory tract diseases and lung cancer in women. We have also reported a flattening of educational inequalities in life expectancy in men after year 2000, while inequalities continue to increase in women [7]. Using national cause specific mortality data, we build on our previous work to examine if the educational inequalities in mortality in Norway have continued to increase after the millennium, and which causes are important regarding the educational inequalities.

\section{Methods}

Data was compiled by Statistics Norway and based on individual records from the Norwegian Cause of Death Registry and the National Education Data Base, and linked using the personal identification number unique to every Norwegian resident. Number of person years and numbers of deaths were summed up for each year 1961 to 2010 for those aged 45 to 74 years that individual year. Five decades were constructed by adding up person years and deaths between January $1^{\text {st }}$ and December $31^{\text {st }}$ in the periods 1961-1969, 1970-1979, 1980-1989, 19901999, and 2000-2009. The study included 708,449 deaths and 62.3 million person years (Table 1). Data was stratified by gender, five year age groups and in the three educational groups basic, secondary and tertiary. Basic education comprised those with nine years of schooling (seven years in the 1960s), the secondary group comprised those with primary and secondary education (10-12 years), and the tertiary group comprised those with post-secondary education (13+ years; college and university). Data on education was almost complete with only $0.9-1.3 \%$ missing all decades. The education stratification for all our analyses, and all decades, is based on Statistics Norway's revision of 2006, when the definitions were changed to be more in line with international criteria [8]. The new criteria are stricter regarding reaching secondary education, and with the new classification the basic education group increased from $19.0 \%$ to $32.8 \%$ in 2005 , while the secondary education group was reduced from $56.7 \%$ to $42.4 \%$ [8]. Tertiary education had only a minor change from $24.3 \%$ to $24.8 \%$. In this report we have re-analyzed the data from all periods according to the new criteria. Overall, the tertiary educated group increased steadily in size from $6 \%$ in the 1960 s to $25 \%$ in the 2000 s in men and from $3 \%$ to $22 \%$ in women (Table 1).

Causes of death were categorized according to the International Classification of Diseases using the 8th and ninth revision until 1996 and the 10th revision thereafter. Deaths were grouped in seven groups (ICD-10 codes): cancer of lung (C32-C34), other cancer (C00-C32, C35-C97), cardiovascular diseases (I00-I99), suicide (X60-X84), external causes (excluding suicide) (V01-Y89), chronic lower respiratory tract diseases (J40-J47), and other causes. Bridging between versions of ICD-8 to ICD-10 was done using Eurostat's European Short List of Causes of Death [9].

\section{Statistical methods}

Age adjusted mortality rates per 100,000 person years were calculated using the direct method and European standard population weights (ISD1976) [10]. Two regression based indices of inequality were used to take into account the change in educational distribution over the five decades [11]. When studying mortality over time, and in the situation with falling mortality rates across all educational strata, absolute inequalities may be stable over time, while relative inequalities are increasing. Because of this we included both an absolute and a relative measure of inequality, which is recommended when studying health inequalities [12]. The Slope Index of Inequality (SII) is an epidemiological measure of absolute inequality in health applicable to ordinal socioeconomic variables [12], and the corresponding measure on the relative scale is The Relative Index of Inequality (RII). When we refer to results regarding absolute mortality inequalities in the paper it is the SII we refer to, and regarding relative mortality inequalities we refer to the RII. These indices take into account the distribution of educational groups and are useful when comparing social inequalities over time or between countries. These indices can be interpreted as the increased risk of dying related to be on a lower level in the educational hierarchy. To calculate these indices the educational groups were ordered from lowest to highest level of education and each group was assigned a so-called Ridit-score (which is the percentage of the population with higher socioeconomic position, here education) [12]. The Poisson regression model was used to estimate the two inequality indices with 95\% confidence intervals, regressing the age adjusted number of deaths (age adjusted rate multiplied with the person years) on the Ridit-score (continuous) 
Table 1 Background table

\begin{tabular}{|c|c|c|c|c|c|}
\hline & $1960 \mathrm{~s}$ & 1970s & $1980 \mathrm{~s}$ & 1990s & $2000 \mathrm{~s}$ \\
\hline Educational level & \multicolumn{5}{|c|}{ Number of deaths } \\
\hline \multicolumn{6}{|l|}{ Men } \\
\hline Basic & 57558 & 68257 & 60498 & 43298 & 27688 \\
\hline Secondary & 19725 & 31488 & 37090 & 35028 & 30839 \\
\hline Tertiary & 3489 & 5532 & 6723 & 8161 & 9013 \\
\hline Total & 80772 & 105277 & 104311 & 86487 & 67540 \\
\hline \multicolumn{6}{|l|}{ Women } \\
\hline Basic & 43539 & 45396 & 38394 & 30054 & 20526 \\
\hline Secondary & 8105 & 13906 & 15885 & 17212 & 17450 \\
\hline Tertiary & 1419 & 1888 & 2326 & 3204 & 4758 \\
\hline \multirow[t]{2}{*}{ Total } & 53063 & 61190 & 56605 & 50470 & 42734 \\
\hline & \multicolumn{5}{|c|}{ Number of person years (\%) } \\
\hline \multicolumn{6}{|l|}{ Men } \\
\hline Basic & $3318547(66)$ & $3367182(56)$ & $2726452(47)$ & $2145114(34)$ & $1836114(25)$ \\
\hline Secondary & $1437370(29)$ & $2136814(36)$ & $2381412(41)$ & $2907905(46)$ & $3584177(50)$ \\
\hline Tertiary & $282055(6)$ & $494505(8)$ & $699045(12)$ & $1203933(19)$ & $1813014(25)$ \\
\hline Total & $5037972(100)$ & $5998501(100)$ & $5806909(100)$ & $6256952(100)$ & $7233305(100)$ \\
\hline \multicolumn{6}{|l|}{ Women } \\
\hline Basic & $4081861(75)$ & $4214395(65)$ & $3544338(57)$ & $2766130(42)$ & $2232559(31)$ \\
\hline Secondary & $1149819(21)$ & $1944846(30)$ & $2257147(36)$ & $2867124(44)$ & $3420863(47)$ \\
\hline Tertiary & $186186(3)$ & $314531(5)$ & $464903(7)$ & $898462(14)$ & $1639013(22)$ \\
\hline \multirow[t]{2}{*}{ Total } & $5417866(100)$ & $6473772(100)$ & $6266388(100)$ & $6531716(100)$ & $7292435(100)$ \\
\hline & \multicolumn{5}{|c|}{ Mortality rate (per 100000 py), age adjusted } \\
\hline \multicolumn{6}{|l|}{ Men } \\
\hline Basic & 1618.1 & 1742.2 & 1713.1 & 1557.4 & 1302.3 \\
\hline Secondary & 1506.9 & 1512.6 & 1423.1 & 1170.3 & 883.1 \\
\hline Tertiary & 1320.2 & 1224.1 & 1041.5 & 803.9 & 574.3 \\
\hline Total & 1569.7 & 1617.7 & 1513.3 & 1232.5 & 912.1 \\
\hline \multicolumn{6}{|l|}{ Women } \\
\hline Basic & 938.1 & 871.4 & 785.7 & 779.9 & 746.4 \\
\hline Secondary & 767.5 & 689.2 & 630.3 & 569.5 & 495.9 \\
\hline Tertiary & 738.5 & 587.1 & 529.8 & 434.2 & 360.7 \\
\hline Total & 895.0 & 802.9 & 710.7 & 640.0 & 542.2 \\
\hline
\end{tabular}

Number of deaths, person years and mortality rate by educational level, period and gender for age $45-74$ years.

and decade (categorical variable) and their interaction terms, specifically for each gender:

$\ln ($ age adjusted number of deaths $)=\ln ($ personyears $)+a$ + b*ridit

+c"decade1970+d"decade1980+e*decade1990

$+f^{*}$ decade 2000

+g*ridit_decade1970+h"ridit_decade1980

+i"ridit_decade1990+j"ridit_decade2000 +error,

where $\ln$ (person years) is the natural logarithm for person years, $a$ is the intercept, $b$ is the coefficient for the Ridit- score, $\mathrm{c}-\mathrm{f}$ are the coefficients for the decades and g-j are the coefficients for the interaction terms Ridit-score by decade.

The SII (for the 1960s) was calculated post-regression (using the nlcom-command in Stata) as a nonlinear combination of the estimated coefficients as: SII_1960 = $100,000 * \exp ([a+b] / a)$. For other decades, for example 1970, SII was estimated as: SII_1970 $=100,000^{*} \exp ([\mathrm{a}+$ $\mathrm{b}+\mathrm{c}+\mathrm{g}] /[\mathrm{a}+\mathrm{c}])$. A similar approach was used to estimate SII for the other decades using the appropriate decade-variables and the interaction term Ridit-score by decade. To test for differences in SII between decades, combinations of the above estimates were used, for 
example the difference between 1970 and 1960: SII_1970 SII_1960. By including the interaction term Ridit-score by decade it was possible to test for difference in SII between decades. For a test of the trend over the whole period a similar model as specified above was used, with decade as a continuous variable labelled $0,1,2,3$, 4, where 0 represented 1960s, 1 represented 1970s, and so on. A similar approach as described above was used to estimate the RII, and the estimation was based on the exact same model as used for the SII. The post-regression-calculation is a bit simpler for the RII than the SII because the RII is just the exponentiated Ridit-score-coefficient. Thus, the RII for the 1960s is RII_1960 = exp([b]), and for the subsequent periods the relevant interaction terms are added. Stata version 12 was used for all analyses.

The study has been performed with the approval of The Regional Committee for Medical and Health Research Ethics in Norway, and is in compliance with the Helsinki Declaration.

\section{Results}

In men, absolute educational inequalities (SII) in total mortality flattened out after year 2000 - in fact there was a $2 \%$ non-significant $(\mathrm{p}=0.56)$ drop between the periods 1990-99 and 2000-09 (calculated as: (SII_2000 SII_1990)/SII_2000 $=(1035-1050) / 1050$ (Table 2). This happened after steadily, significantly increasing absolute inequalities all the way back to the 1960s. In women there was a drop in absolute inequalities from the 1970s to 1980 s, but thereafter a steady increase, also after year 2000 (p-value <0.01). Relative inequalities (RII) increased sharply in men and women in all decades ( $\mathrm{p}<$ 0.001), except from 1970s to 1980s in women where inequalities were stable (Table 2).

Another noteworthy change in the post millennium decade from previous decades was the large drop in absolute inequality in CVD mortality among men; the SII for CVD dropped from 508 to 357 deaths per 100,000 (test of change in absolute inequalities: $\mathrm{p}<0.001$ ) (Figure 1a). Since the 1960s CVD has been the largest driver of the absolute educational inequalities in total mortality in both men and women. Overall, there was a drop in CVD mortality for all educational groups the last decades, in both men and women, and in the last decade this drop was greatest in the lowest educational group (Table 3). The impact of educational inequalities in CVD mortality to the total absolute mortality gap by education was reduced from $48 \%$ to $34 \%$ in men, and from $46 \%$ to $27 \%$ in women (Figures 1a and b). In men, death inequalities for all other causes increased in the same period (Figure 1a). In women there was a steady decrease in absolute CVD inequalities since the 1970s, and this decrease continued after millennium (test of change in absolute inequalities between 1990-99 and 2000-09: p < 0.001) (Figure 1b).

Furthermore an important finding is the substantial widening in absolute inequalities in lung cancer and chronic

Table 2 Absolute and relative educational inequalities in mortality in Norway over five decades, by gender

\begin{tabular}{|c|c|c|c|c|}
\hline \multirow[b]{2}{*}{ Decade } & \multicolumn{2}{|r|}{ Men } & \multicolumn{2}{|r|}{ Women } \\
\hline & $\begin{array}{l}\text { Absolute inequality* } \\
(95 \% \mathrm{Cl})\end{array}$ & $\begin{array}{l}\text { Absolute change in inequality* } \\
\text { from previous period }\end{array}$ & $\begin{array}{l}\text { Absolute inequality* } \\
(95 \% \mathrm{Cl})\end{array}$ & $\begin{array}{l}\text { Absolute change in inequality* } \\
\text { from previous period }\end{array}$ \\
\hline $1960 \mathrm{~s}$ & $313(265,361)$ & & $376(336,416)$ & \\
\hline 1970s & $626(583,670)$ & $313(p<0.01)$ & $427(395,458)$ & $51(p=0.05)$ \\
\hline $1980 \mathrm{~s}$ & $838(796,879)$ & $211(p<0.01)$ & $364(336,391)$ & $-63(p<0.01)$ \\
\hline 1990s & $1050(1013,1087)$ & $212(p<0.01)$ & $495(470,519)$ & $130(p<0.01)$ \\
\hline $2000 \mathrm{~s}$ & $1035(1005,1066)$ & $-14(p=0.561)$ & $551(529,572)$ & $56(p<0.01)$ \\
\hline \multirow[t]{2}{*}{$P$-value for linear trend } & 0.018 & & 0.025 & \\
\hline & \multicolumn{2}{|r|}{ Men } & \multicolumn{2}{|r|}{ Women } \\
\hline Decade & $\begin{array}{l}\text { Relative inequality** } \\
(95 \% \mathrm{Cl})\end{array}$ & $\begin{array}{l}\text { Change in relative inequality } \\
\text { from previous period }\end{array}$ & $\begin{array}{l}\text { Relative inequality** } \\
(95 \% \mathrm{Cl})\end{array}$ & $\begin{array}{l}\text { Change in relative inequality } \\
\text { from previous period }\end{array}$ \\
\hline $1960 \mathrm{~s}$ & $1.21(1.18,1.26)$ & & $1.52(1.46,1.59)$ & \\
\hline $1970 \mathrm{~s}$ & $1.46(1.42,1.50)$ & $0.18(p<0.01)$ & $1.69(1.63,1.76)$ & $0.11(p<0.01)$ \\
\hline $1980 \mathrm{~s}$ & $1.71(1.67,1.76)$ & $0.16(p<0.01)$ & $1.67(1.61,1.73)$ & $-0.01(p=0.59)$ \\
\hline 1990s & $2.24(2.18,2.30)$ & $0.27(p<0.01)$ & $2.14(2.07,2.22)$ & $0.25(p<0.01)$ \\
\hline $2000 \mathrm{~s}$ & $2.95(2.86,3.03)$ & $0.27(p<0.01)$ & $2.72(2.62,2.82)$ & $0.24(p<0.01)$ \\
\hline P-value for linear trend & $<0.001$ & & 0.013 & \\
\hline
\end{tabular}

*Slope Index of Inequality, SII. The number can be interpreted as the difference in absolute risk (unit is deaths per 100,000 person years) of dying related to be on a lower level in the educational hierarchy compared to be at the top.

**Relative Index if Inequality, RII. The number can be interpreted as the mortality incidence rate ratio for those in the lower level in the educational hierarchy relative to those at the top.

${ }^{* * *}$ Change in $\ln (\mathrm{RII})$. Since RII is estimated on a log-scale, we investigate change using $\ln (\mathrm{RII})$ as this converts it to linear scale. 


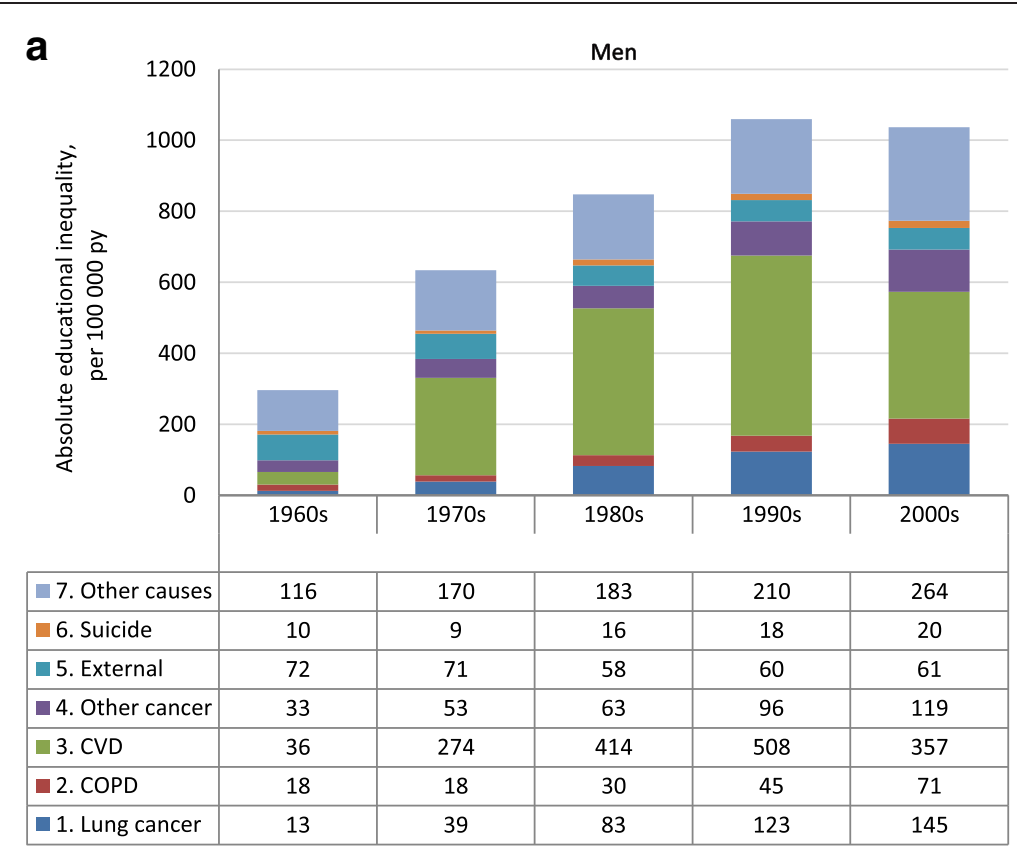

b

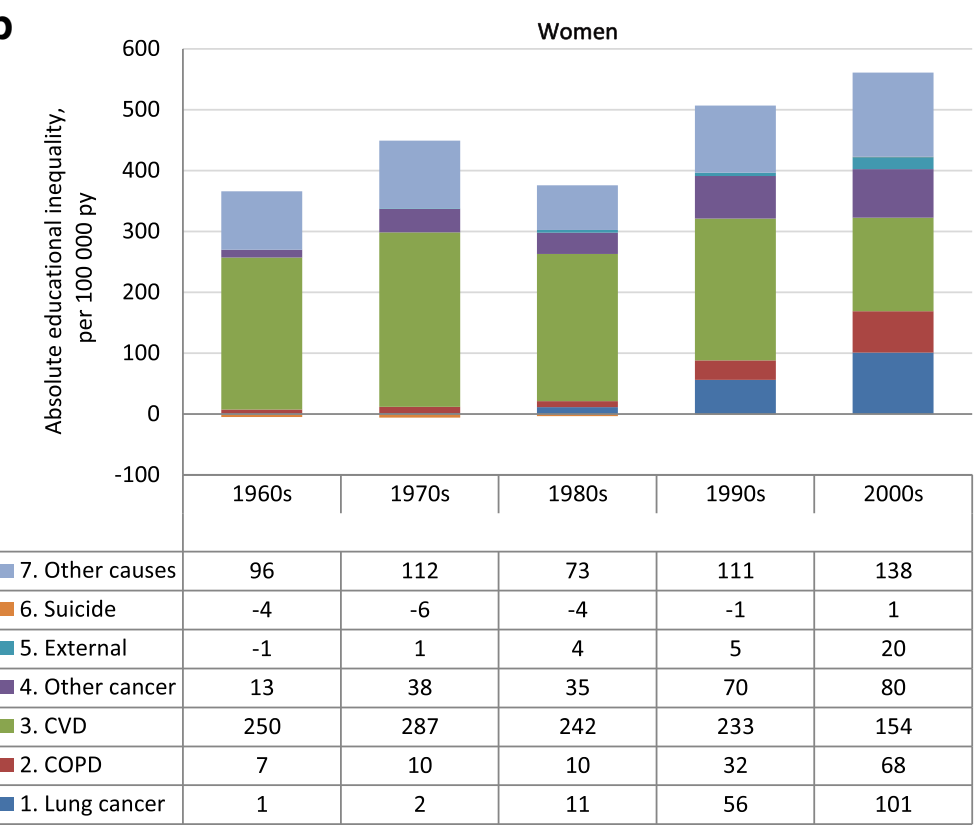

Figure 1 Absolute inequality (SII) in total and cause specific mortality over five decades (1961-2009), age adjusted. a. Men. Absolute educational inequality* in cause specific mortality for Norwegians aged 45-74 years over five decades (1961-2009), age-adjusted. The total height of the bars represent absolute inequality in all-cause mortality (per 100,000 person years). b. Women. Absolute educational inequality* in cause specific mortality for Norwegians aged 45-74 years over five decades (1961-2009), age-adjusted. The total height of the bars represent absolute inequality in all-cause mortality (per 100,000 person years).

respiratory disease in the post millennium decade among women (test of change in absolute inequalities between 1990-99 and 2000-09: p < 0.001, Figure 1b). In women, this widening gap for these causes is a continuation of a significantly widening trend since the 1980s (test of change in absolute inequalities: $\mathrm{p}<0.001$ between each decade 1980s to 2000s).
In women, educational inequalities in deaths due to lung cancer and chronic respiratory diseases combined constituted $30 \%$ of the total absolute mortality inequality in the post millennium decade, and were thereby more important than CVD (27\%) regarding the total mortality gap by education (Figure 1b). In comparison, in all previous decades inequalities in deaths from CVD constituted 
Table 3 Cause specific mortality rates (in 7 cause specific groups) by gender, educational level and period for the ages $45-74$ years

\begin{tabular}{|c|c|c|c|c|c|}
\hline & $1960 s$ & 1970 s & $1980 \mathrm{~s}$ & $1990 \mathrm{~s}$ & $2000 s$ \\
\hline \multicolumn{6}{|c|}{ Educational level } \\
\hline \multicolumn{6}{|c|}{ 1. Lung cancer mortality rate (per 100000 py), age adjusted } \\
\hline \multicolumn{6}{|l|}{ Men } \\
\hline Basic & 57.1 & 88.3 & 121.8 & 140.7 & 144.7 \\
\hline Secondary & 54.1 & 76.0 & 95.0 & 97.4 & 91.4 \\
\hline Tertiary & 40.1 & 52.1 & 55.1 & 53.7 & 45.1 \\
\hline Total & 50.4 & 72.1 & 90.6 & 97.2 & 93.8 \\
\hline \multicolumn{6}{|l|}{ Women } \\
\hline Basic & 9.2 & 15.3 & 30.1 & 61.8 & 93.8 \\
\hline Secondary & 7.9 & 14.9 & 26.0 & 38.3 & 49.6 \\
\hline Tertiary & 14.1 & 12.5 & 20.4 & 24.3 & 26.1 \\
\hline Total & 10.4 & 14.2 & 25.5 & 41.5 & 56.5 \\
\hline \multicolumn{6}{|c|}{ 2. COPD mortality rate (per 100000 py), age adjusted } \\
\hline \multicolumn{6}{|l|}{ Men } \\
\hline Basic & 21.3 & 30.5 & 35.4 & 45.0 & 58.5 \\
\hline Secondary & 14.9 & 25.1 & 25.9 & 30.9 & 31.3 \\
\hline Tertiary & 9.1 & 13.9 & 11.5 & 13.2 & 11.7 \\
\hline Total & 15.1 & 23.2 & 24.3 & 29.7 & 33.9 \\
\hline \multicolumn{6}{|l|}{ Women } \\
\hline Basic & 6.5 & 8.8 & 12.8 & 28.2 & 50.4 \\
\hline Secondary & 3.9 & 5.0 & 8.5 & 15.1 & 22.1 \\
\hline Tertiary & 3.1 & 3.0 & 6.0 & 7.5 & 7.3 \\
\hline Total & 4.5 & 5.6 & 9.1 & 16.9 & 26.6 \\
\hline
\end{tabular}

Men

$\begin{array}{llllll}\text { Basic } & 804.4 & 886.6 & 843.7 & 667.2 & 404.4 \\ \text { Secondary } & 809.0 & 794.2 & 707.9 & 483.7 & 259.7 \\ \text { Tertiary } & 708.7 & 635.6 & 500.0 & 305.2 & 156.3 \\ \text { Total } & 774.0 & 772.1 & 683.8 & 485.4 & 273.5\end{array}$

Women

\begin{tabular}{llllrr} 
Basic & 423.4 & 377.5 & 304.3 & 244.2 & 157.9 \\
Secondary & 313.2 & 258.3 & 201.9 & 146.9 & 90.7 \\
Tertiary & 296.0 & 203.1 & 148.9 & 89.2 & 52.9 \\
Total & 344.2 & 279.6 & 218.4 & 160.1 & 100.5 \\
\hline \multicolumn{4}{r}{ 4. Other cancer mortality rate (per 100 000 py), age adjusted }
\end{tabular}
Men

$\begin{array}{llllll}\text { Basic } & 296.1 & 318.8 & 321.4 & 321.4 & 289.2 \\ \text { Secondary } & 283.7 & 299.9 & 303.2 & 290.4 & 253.3 \\ \text { Tertiary } & 265.9 & 271.0 & 262.9 & 246.7 & 201.7 \\ \text { Total } & 281.9 & 296.6 & 295.8 & 286.2 & 248.0\end{array}$

Women

Basic

Secondary
$282.6 \quad 274.8 \quad 273.9 \quad 248.3$

$\begin{array}{lllll}268.0 & 268.8 & 260.4 & 248.1 & 213.9\end{array}$
Table 3 Cause specific mortality rates (in 7 cause specific groups) by gender, educational level and period for the ages 45-74 years (Continued)

\begin{tabular}{|c|c|c|c|c|c|}
\hline & $1960 \mathrm{~s}$ & 1970s & 1980s & 1990s & $2000 \mathrm{~s}$ \\
\hline \multicolumn{6}{|c|}{ Educational level } \\
\hline Tertiary & 258.4 & 243.1 & 246.6 & 218.7 & 190.5 \\
\hline Total & 266.3 & 264.9 & 260.6 & 246.9 & 217.6 \\
\hline \multicolumn{6}{|c|}{ 5. External causes mortality rate (per 100000 py), age adjusted } \\
\hline \multicolumn{6}{|l|}{ Men } \\
\hline Basic & 79.1 & 85.1 & 77.3 & 67.9 & 65.1 \\
\hline Secondary & 51.4 & 56.8 & 55.0 & 45.2 & 40.5 \\
\hline Tertiary & 36.6 & 41.7 & 37.2 & 26.6 & 23.2 \\
\hline Total & 55.7 & 61.2 & 56.5 & 46.6 & 43.0 \\
\hline \multicolumn{6}{|l|}{ Women } \\
\hline Basic & 19.4 & 20.8 & 20.5 & 17.7 & 25.5 \\
\hline Secondary & 19.4 & 20.8 & 18.8 & 15.9 & 14.7 \\
\hline Tertiary & 22.9 & 19.0 & 17.6 & 13.6 & 12.4 \\
\hline Total & 20.6 & 20.2 & 19.0 & 15.7 & 17.5 \\
\hline
\end{tabular}

\section{Men}

$\begin{array}{llllll}\text { Basic } & 21.8 & 26.8 & 36.2 & 31.3 & 28.5 \\ \text { Secondary } & 16.7 & 22.1 & 27.8 & 23.3 & 18.6 \\ \text { Tertiary } & 18.6 & 22.6 & 27.4 & 19.3 & 14.4 \\ \text { Total } & 19.0 & 23.8 & 30.5 & 24.6 & 20.5\end{array}$

Women

\begin{tabular}{|c|c|c|c|c|c|}
\hline Basic & 5.8 & 8.0 & 12.5 & 10.2 & 9.5 \\
\hline Secondary & 7.2 & 10.3 & 13.6 & 10.4 & 8.6 \\
\hline Tertiary & 10.3 & 14.2 & 16.7 & 11.3 & 9.1 \\
\hline Total & 7.7 & 10.8 & 14.3 & 10.6 & 9.1 \\
\hline \multicolumn{6}{|c|}{ 7. Other causes mortality rate (per 100000 py), age adjusted } \\
\hline \multicolumn{6}{|l|}{ Men } \\
\hline Basic & 302.5 & 304.4 & 273.9 & 273.0 & 293.0 \\
\hline Secondary & 254.1 & 237.1 & 203.7 & 190.3 & 173.8 \\
\hline Tertiary & 225.2 & 186.3 & 143.1 & 128.1 & 111.6 \\
\hline Total & 260.6 & 242.6 & 206.9 & 197.1 & 192.8 \\
\hline \multicolumn{6}{|l|}{ Nomen } \\
\hline Basic & 172.9 & 157.8 & 128.7 & 140.2 & 154.1 \\
\hline Secondary & 132.2 & 110.7 & 99.6 & 91.8 & 91.1 \\
\hline Tertiary & 115.4 & 90.8 & 72.9 & 66.1 & 59.1 \\
\hline Total & 140.2 & 119.9 & 100.4 & 99.4 & 101.4 \\
\hline
\end{tabular}

most of the total mortality gap in women $(69 \%$ in the 1960 s, $65 \%$ in the 1970 s and 1980 s, $46 \%$ in the 1990 s, Figure $1 \mathrm{~b})$.

Also in men, absolute inequalities in lung cancer and chronic respiratory diseases increased in the last decade 2000-2009, and this increase was significant each decade since the 1970s (lung cancer and chronic respiratory 
diseases combined constituted $10 \%$ of absolute inequalities in total mortality in the 1960s, $9 \%$ in the 1970 s, $14 \%$ in the 1980 s and $16 \%$ in the 1990 s, Figure 1a). In men, these causes combined constituted $21 \%$ of the total absolute mortality inequality during 2000-2009, but CVD was still more important (34\%), as it was in the previous three decades (43\% in the 1970s, $49 \%$ in the 1980 s and $48 \%$ in the 1990s) (Figure 1a).

Absolute educational inequalities in external causes and suicide were stable over time in men, and constituted in combination $8 \%$ of the total absolute male mortality inequality during 2000-2009. In women the corresponding figure was $4 \%$. Absolute educational inequalities in other cancers and other causes increased after millennium and constituted $37 \%$ and $39 \%$ of the total educational inequalities in mortality in men and women respectively.

\section{Discussion}

For the first time in five decades absolute mortality inequalities have stopped to increase among men, even with a tendency toward a drop the last decade. This levelling out in inequalities among men is mainly due to a large and significant drop in CVD mortality inequalities. Due to falling mortality rates across all educational strata, relative educational inequalities in mortality are still on the rise for Norwegian men and women, as is the case in North, West and East of Europe [13]. For women this increase also holds for absolute inequalities, in line with our previous reports [2,7]. The impact of educational inequalities in CVD on the total mortality gap was substantially reduced in both men and women the last decade. In women this decrease in inequality started already in the 1990s, but for men, the fall in CVD mortality inequalities was first seen in the last decade.

The overall rates of CVD mortality have decreased markedly from 1970s, and particularly marked from the middle of 1980s for ischemic heart disease, especially in men [14]. In both men and women, this fall in CVD mortality was more pronounced in the higher educational groups until year 2000, while from 2000 the fall was greatest in the lowest educational group, leading to flattening educational inequalities in the last decade. For women this CVD-driven drop of inequality was not out-weighted by the large increase in inequalities in deaths from lung cancer and chronic respiratory diseases, resulting in a continued increase of the gap in total mortality between those at the top and bottom in the educational hierarchy. Thus, even if CVD mortality inequalities continued to narrow in women the last decade, inequalities in total mortality increased. A populationbased regional Norwegian survey found that the educational trend in serum cholesterol levels weakened significantly between 1994 and 2008 [15]. If these results are nationally representative, this trend predicts cessation of the increase in the educational gap in CVD mortality, consistent with our findings in men.

As the decrease in coronary heart disease mortality in the Western countries during the last decades of the last century is related to better treatment [16], more coronary heart disease patients are living with rather than dying from coronary heart disease and thus are at risk of dying of other risk factor-related diseases, especially long term smoking-related diseases such as chronic obstructive pulmonary disease and cancer. Also, smoking cessation affects cardiovascular health more immediately than cancers [17].

Norway has the position as the country in Europe with the largest educational inequalities in smoking [18], and in Norway educational inequalities in smoking have been on the rise since the 1970s [19], with a possible fall after 2009 [20]. It seems that smoking matters more in Norway regarding educational inequalities in total mortality compared with other European countries [21-23]. In Finland there are large educational inequalities in female smoking, and smoking was the main driver behind the increased inequalities in female mortality during 1971-2010, while among men smoking was not as important [24]. Similar findings have been reported in New-Zealand [25]. In South-European countries there are smaller educational inequalities in smoking, which is also reflected in smaller differences in smoking-related deaths [21]. Also in US there seems to be other causes than the smoking, which are driving the increased educational inequalities in mortality [26].

Lung cancer mortality started declining in adult men during the mid 1990s, after steady increase since the 1950s, while in women lung cancer mortality incidence started to increase later, around 1970, and did not decline until 2010 [14,27]. In line with the world-wide tobacco epidemic described by Lopez et al. in 1994 [28], higher educated people are being affected mostly in the epidemic's early stages $[27,29]$. Those in the higher educational groups were the first to pick up smoking and also the first to abstain or quit [27], especially among women [30]. In men, the prevalence of daily smoking started decreasing around 1970, from 52\% in 1973 to $19 \%$ in 2010 , while in women the corresponding figures were $32 \%$ and $19 \%$ [31]. Prevalence has continued to decrease to $15 \%$ in men and $14 \%$ in women in 2013.

\section{Conclusions}

In men absolute educational inequalities in total mortality stopped increasing in the post millennium decade seemingly due to a reduction in inequalities in CVD mortality. In women, inequalities (both on the absolute 
and relative scale) in mortality have continued to widen in Norway after millennium, mostly due to causes of death such as lung cancer and COPD. Educational inequalities in total mortality seem to be moving from CVD mortality being the single most important driver to a more heterogeneous pattern where deaths from several non-communicable diseases contribute. Inequalities in mortality should be monitored closely in the coming years.

\section{Competing interests}

The authors declare that they have no competing interests.

\section{Authors' contributions}

BHS, OAS, EKG, IA, SGI, ØN together had the idea of the paper. BHS and ØN participated in the design. BHS carried out the analyses. BHS, OAS, EKG, IA, SGI, ØN participated in interpretation of data. BHS drafted the paper with help from all the other authors. All authors read and approved the final manuscript.

\section{Acknowledgements}

We thank Kåre Bævre for the preparation of data.

\section{Author details}

${ }^{1}$ Division of epidemiology, Norwegian Institute of Public Health, P.O. Box 4404 Nydalen, NO-0403 Oslo, Norway. ${ }^{2}$ University of Oslo, Institute of Health and Society, Faculty of Medicine, Oslo, Norway. ${ }^{3}$ University of Oslo, Institute of Health Management and Economics, Faculty of Medicine, Oslo, Norway.

\section{Received: 25 June 2014 Accepted: 27 October 2014}

Published: 24 November 2014

\section{References}

1. Mackenbach JP: The persistence of health inequalities in modern welfare states: the explanation of a paradox. Soc Sci Med 2012, 75(4):761-769. doi:10.1016/j.socscimed.2012.02.031 [published Online First].

2. Strand BH, Groholt EK, Steingrimsdottir OA, Blakely T, Graff-Iversen S, Naess O: Educational inequalities in mortality over four decades in Norway: prospective study of middle aged men and women followed for cause specific mortality, 1960-2000. BMJ 2010, 340:c654.

3. Fawcett J, Blakely T, Kunst A: Are mortality differences and trends by education any better or worse in New Zealand? A comparison study with Norway, Denmark and Finland, 1980-1990s. EurJ Epidemiol 2005, 20(8):683-691

4. Mackenbach JP, Bos V, Andersen O, Cardano M, Costa G, Harding S, Reid A Hemstrom O, Valkonen T, Kunst AE: Widening socioeconomic inequalities in mortality in six Western European countries. Int J Epidemiol 2003, 32(5):830-837

5. Kautto M, Fritzell J, Hvinden B, Kvist J, Uusitalo H: Conclusion: Nordic welfare states $i$ the European context. In Nordic Welfare States in the European Context. Edited by Kautto M, Fritzell J, Hvinden B, et al. London: Routhledge; 2001.

6. Rostgaard T, Lethos J: Health and social care systems: how different is the Nordic model? In Nordic Welfare States in the European Context. Edited by Kautto M, Fritzell J, Hvinden B, et al. London: Routhledge; 2001.

7. Steingrimsdottir OA, Naess O, Moe JO, Groholt EK, Thelle DS, Strand BH, Baevre K: Trends in life expectancy by education in Norway 1961-2009. Eur J Epidemiol 2012, 27(3):163-171. doi:10.1007/s10654-012-9663-0 [published Online First].

8. Jørgensen T: Befolkningens utdanningsnivå. Nye definisjoner av utdanningsnivåer. [In Norwegian]. Artikler. Oslo: Statistics Norway; 2006.

9. Eurostat: Eurostat's European Short List of Causes of Death Secondary Eurostat's European Short List of Causes of Death 2014. [http://epp. eurostat.ec.europa.eu/statistics_explained/index.php/Glossary: European_shortlist_of_causes_of_death]

10. Ahmad OB, Boschi-Pinto C, Lopez AD, Murray C, Lozano R, Inoue M: Age standardization of rates: a new WHO standard. In GPE Discussion Paper Series. Volume No.31. Geneva, Switzerland: WHO; 2001.
11. Mackenbach JP, Kunst AE: Measuring the magnitude of socio-economic inequalities in health: an overview of available measures illustrated with two examples from Europe. Soc Sci Med 1997, 44(6):757-771.

12. Harper S, Lynch J: Measuring health inequalities. In Methods in Social Epidemiology. Edited by Oakes JM, Kaufman JS. San Francisco, USA: Jossey-Bass; 2006

13. Mackenbach JP, Kulhánová I, Menvielle G, Bopp M, Borrell C, Costa G, Deboosere P, Esnaola S, Kalediene R, Kovacs K, Leinsalu M, Martikainen P, Regidor E, Rodriguez-Sanz M, Strand BH, Hoffmann R, Eikemo TA, Ostergren O, Lundberg O, for the Eurothine and EURO-GBD-SE Consortiums: Trends in inequalities in premature mortality: a study of 3.2 million deaths in 13 European countries. J Epidemiol Community Health 2014, doi:10.1136/jech-2014-204319 [published Online First].

14. Vollset SE: Risk and causes of death between 40 and 70 years of age in the Nordic countries 1951-2010. Scand J Public Health 2013, doi:10.1177/ 1403494813491032 [published Online First].

15. Eggen $A E$, Mathiesen EB, Wilsgaard T, Jacobsen BK, Njolstad I: Trends in cardiovascular risk factors across levels of education in a general population: is the educational gap increasing? The Tromso study 1994-2008. J Epidemiol Community Health 2014, doi:10.1136/jech-2013203428 [published Online First].

16. Ford ES, Ajani UA, Croft JB, Critchley JA, Labarthe DR, Kottke TE, Giles WH, Capewell S: Explaining the decrease in U.S. deaths from coronary disease, 1980-2000. N Engl J Med 2007, 356(23):2388-2398. doi:10.1056/ NEJMsa053935 [published Online First].

17. Tverdal A, Thelle D, Stensvold I, Leren P, Bjartveit K: Mortality in relation to smoking history: 13 years' follow-up of 68,000 Norwegian men and women 35-49 years. J Clin Epidemiol 1993, 46(5):475-487.

18. Cavelaars $A E$, Kunst $A E$, Geurts JJ, Crialesi R, Grötvedt L, Helmert $U$, Lahelma E, Lundberg O, Matheson J, Mielck A, Rasmussen NK, Regidor E, do Rosário-Giraldes M, Spuhler T, Mackenbach JP: Educational differences in smoking: international comparison. BMJ 2000, 320(7242):1102-1107.

19. Helleve A, Weisæth A, Lindbak R: Tall om Tobakk. Helsedirektoratet: Helsedirektoratet; 2010.

20. Larsen K, Hansen G: Social ulighet $i$ sundhed - mere vilkår end valg. Indsigter og forklaringer på norske forhold. Underlagsrapport til Sosial ulikhet i helse: En norsk kunnskapsoversikt. Oslo: Oslo and Akershus University College of Applied Sciences; 2013.

21. Mackenbach JP, Stirbu I, Roskam AJ, Schaap MM, Menvielle G, Leinsalu M, Kunst AE: Socioeconomic inequalities in health in 22 European countries. N Engl J Med 2008, 358(23):2468-2481.

22. Kulik MC, Hoffmann R, Judge K, Looman C, Menvielle G, Kulhánová I, Toch M, Ostergren O, Martikainen P, Borrell C, Rodríguez-Sanz M, Bopp M, Leinsalu M, Jasilionis D, Eikemo TA, Mackenbach JP: Smoking and the potential for reduction of inequalities in mortality in Europe. Eur J Epidemiol 2013, 28(12):959-971. doi:10.1007/s1 0654-013-9860-5 [published Online First].

23. Hoffmann R, Eikemo TA, Kulhanova I, Dahl E, Deboosere P, Dzurova D, van Oyen H, Rychtarikova J, Strand BH, Mackenbach JP: The potential impact of a social redistribution of specific risk factors on socioeconomic inequalities in mortality: illustration of a method based on population attributable fractions. J Epidemiol Community Health 2013, 67(1):56-62. doi:10.1136/jech-2011-200886 [published Online First].

24. Martikainen P, Ho JY, Preston S, Elo IT: The changing contribution of smoking to educational differences in life expectancy: indirect estimates for Finnish men and women from 1971 to 2010. J Epidemiol Community Health 2013, 67(3):219-224. doi:10.1136/jech-2012-201266 [published Online First].

25. Pega F, Blakely T, Carter K, Sjoberg O: The explanation of a paradox? A commentary on Mackenbach with perspectives from research on financial credits and risk factor trends. Soc Sci Med 2012, 75(4):770-773. doi:10.1016/j.socscimed.2012.03.052 [published Online First].

26. Cutler DM, Lange F, Meara E, Richards-Shubik S, Ruhm CJ: Rising educational gradients in mortality: the role of behavioral risk factors. J Health Econ 2011, 30(6):1174-1187. doi:10.1016/j.jhealeco.2011.06.009 [published Online First].

27. Lund KE, Lund M: [Smoking and social inequality in Norway 1998-2000]. Tidsskrift for den Norske laegeforening: tidsskrift for praktisk medicin, ny raekke 2005, 125(5):560-563.

28. Lopez AD, Collishaw NE, Piha T: A descriptive model of the cigarette epidemic in developed countries. Tob Control 1994, 3(3):242-247.

29. Lund KE, Lund M, Bryhni A: [Tobacco consumption among men and women 1927-2007]. Tidsskrift for den Norkke laegeforening: tidsskrift for 
praktisk medicin, ny raekke 2009, 129(18):1871-1874. doi:10.4045/ tidsskr.08.0248 [published Online First].

30. Lund $M$, Lund $K E$, Rise J: [Socioeconomic differences in smoking cessation among adults]. Tidsskrift for den Norske laegeforening: tidsskrift for praktisk medicin, ny raekke 2005, 125(5):564-568.

31. Statistics Norway: Secondary Statistics Norway. 2014, [https://www.ssb.no/ statistikkbanken/selectvarval/saveselections.asp]

doi:10.1186/1471-2458-14-1208

Cite this article as: Strand et al:: Trends in educational inequalities in cause specific mortality in Norway from 1960 to 2010: a turning point for educational inequalities in cause specific mortality of Norwegian men after the millennium? BMC Public Health 2014 14:1208.

\section{Submit your next manuscript to BioMed Central and take full advantage of:}

- Convenient online submission

- Thorough peer review

- No space constraints or color figure charges

- Immediate publication on acceptance

- Inclusion in PubMed, CAS, Scopus and Google Scholar

- Research which is freely available for redistribution 